Article

\title{
The Healing Spirituality of Eastern Orthodoxy: A Personal Journey of Discovery ${ }^{\dagger}$
}

\author{
Kyriacos C. Markides \\ Department of Sociology, University of Maine Orono, Maine 04469, USA; Markides@maine.edu; \\ Tel.: +1-207-581-2390 \\ $+\quad$ I am grateful to my colleague Michael Lewis and my wife Emily Markides for their critical reading of the \\ first draft.
}

Academic Editor: John A. Jillions

Received: 4 April 2017; Accepted: 2 June 2017; Published: 8 June 2017

\begin{abstract}
It is generally assumed by western scholars and spiritual seekers that mystical, experiential religion and spirituality are primarily a hallmark of the far East, as exemplified by Hinduism, Buddhism, Taoism, and tribal religions like native American shamanism. In this overview, based on thirty years of field research as a sociologist, I have tried to show that such mystical practices and spiritual approaches exist in Eastern Christianity among groups of lay people, as well as in ancient monasteries like those found on Mt. Athos in northern Greece. It is argued that these thousand-year-old practices in the Christian East may contribute to what some thinkers have called the "eye of contemplation", namely the cultivation of the intuitive, spiritual side of human beings that has been repressed over the centuries because of the dominance of rationalism and scientific materialism.
\end{abstract}

Keywords: Eastern Orthodoxy; mysticism; religion; spirituality; healing

It is said that Christianity has two "lungs" one Western and the other Eastern, and that both are needed for proper breathing. It is a metaphor put forward by those who long for the re-establishment of unity that was torn asunder in 1054 when the Pope of Rome and the Patriarch of Constantinople excommunicated each other. As is well known, the trigger for the Great Schism was the notorious-for eastern Christians-Filioque. This was the addition to the Christian creed by the Roman Pope of a word signifying that the Holy Spirit proceeded from the Father "and from the Son", instead of simply "from the Father", as was traditionally stated and continues to be recited to this day during Divine Liturgy by Orthodox Christians.

It is beyond the scope of this paper to explore the theological complexities of that detail in the Christian creed or to elaborate on the historical and geopolitical forces that, over the preceding centuries, had built up the pressures that led to the split. However, what is important to underscore here is the fact that this episode in Christian history had monumental and unintended consequences, not only for Christianity but for the way European Civilization and the world at large have developed. The Western part of Christianity followed a radically different historical experience than its Eastern counterpart. Whereas Roman Catholicism became increasingly more involved in the affairs of this world and more rational in its theological formulations on how to know God, the Eastern part of Christianity became more otherworldly and more focused on the inward and mystical experience of Divinity. The Roman Catholic Church adopted the massive work of Thomas Aquinas, who incorporated into Christian theology the philosophy of Aristotle. This innovation set the foundation for the scientific revolution 
and the parallel development of capitalism. ${ }^{1}$ God was conceived in rational terms, the One who created the universe, governed by rational laws and principles. Therefore, human beings, made in the image of God, are encouraged to apply their God-given reason to understand their world and their Maker. The great monasteries of the West, as leading sociologist of religion Rodney Stark so convincingly demonstrates, became workshops in studying nature. ${ }^{2}$ Western monks were given the green light to experiment and study nature, and in doing so they would come to understand how God governs his Creation. This rational approach to God opened the way for the scientific revolution and the eventual and increasing rationalization of the West. In other words, modernity, material prosperity, technological innovation, social progress and secularism have their roots in theology as developed in the Western "lung" of Christianity.

The Eastern part of Christianity, on the other hand, turned inward, emphasizing an approach to God that was more contemplative, meditative and experiential. ${ }^{3}$ This difference in the approach to God was sealed when Eastern Christianity was taken over by Islamic warriors, culminating at the Fall of Constantinople in 1453 and, later on, the communist takeover of Russia in 1917. The Eastern part of Christianity remained cut off from Western history, such as the further rationalizing developments ushered in by the Protestant Reformation and the on-going disputes between, on the one hand, a science that disentangled itself from its religious origins and moorings and, on the other hand, with Christian theology. The Eastern part of Christianity, playing hardly any role in the external developments of western history, remained pretty much insular in its outlook and more focused on its contemplative approaches as practiced in monasteries like those of Mt. Athos.

Today's Westerners, spiritually exhausted from the dominance of rationalism and materialism, and disenchanted with western, organized religions, have been seeking an outlet in the religions of the Far East like Zen Buddhism, Taoism and Hinduism. They have been looking for a healing spirituality that somehow they could not find within the secularizing ethos dominant in contemporary western culture, particularly as it prevails in universities, which have been my professional world as a sociologist for over forty years. The Eastern part of Christianity, with its experiential, mystical focus and methodologies related to spiritual healing, remains largely unknown in the West. In the rest of this paper I will share my own personal quest and "discovery" of the richness of Eastern Orthodox spirituality and its potential relevance for the future of Christianity and the world at large. It is my quest for the other "lung" of Christianity that may contribute to the healing of what many feel is our spiritually broken world.

My "discovery" of the healing tradition of Eastern Orthodoxy came by way of a serendipitous encounter with a group of lay healers and mystics in Cyprus during the 1980's. This encounter led to several years of field research exploring the world of these uncommon individuals. During this period I became, among other things, a witness to extraordinary feats of healing that defied, at least for me, a rational explanation. Following my exposure to the Cypriot healers and my sensitization to the possibility of the "miraculous" as part of human experience, the way was opened for me through certain coincidences to take a renewed and closer look at the religion of my upbringing. Consequently, since the mid-90's I have been researching and studying the mystical and miracle-filled culture of Eastern Orthodoxy as it is preserved to this day in ancient monasteries like those of Mount Athos, the isolated peninsula in northern Greece. Otherwise known as the Holy Mountain, it has served since the tenth century as a refuge for monks and hermits.

1 See the work of leading sociologist of religion Rodney Stark in several of his pioneering works such as his seminal opus (Stark 2006), and his more recently published (Stark 2014).

2 Ibid.

3 The four-year theological debate in the 14th Century between Orthodox theologian St. Gregory Palamas (monk from Mt. Athos and later Archbishop of Thessaloniki) and the Calabrian Monk Barlaam set the seal of the different approaches in Christian theology between East and West. (See (Meyendorff 1974; Lossky 1997; Ware 1995)). It should be noted, however, that some recent scholarship has focused on areas of convergence between Gregory Palamas and Thomas Aquinas. See for example, (Plested 2012). 
I should point out from the outset that these two pivotal experiences-my work with the lay healers and mystics of Cyprus, followed by my explorations of the spiritual healing tradition of Eastern Orthodoxy—had a profound effect on my worldview and outlook on life. Not surprisingly, the experiences had a radical impact on my academic career as well. Originally trained as a political sociologist studying problems related to nationalist movements and international terrorism, I shifted my focus and research towards the study of religion, spirituality and mysticism. In the following pages, I will share some aspects of this thirty-year intellectual and spiritual odyssey, and try to summarize the key features of the healing spirituality of Eastern Orthodoxy as I have experienced and studied it through my interactions with Athonite elders and hermits. I will then venture to suggest its potential relevance and contribution to contemporary western culture and identify possible weaknesses and obstacles that prevent such a development from occurring.

I must confess that, like most academics, I was at first suspicious of any claims related to presumed miracle healings and the "paranormal" phenomena so much in vogue today in popular culture, and so routinely debunked by the established academic community. My training in social science made me wary of any unusual and extravagant-sounding claims about "miracle" healings, clairvoyant visions and the like that could not be supported by "hard" scientific evidence, meaning controlled and replicable experiments. Furthermore, I have accepted as a matter of course, albeit reluctantly, the underlying tacit assumptions within which modern academic discourse operates; assumptions based on positivism, reductionism, relativism and determinism. That is, that the only truth is the truth discovered by our sense observations aided by the scientific method (positivism); that the only reality "out there" is the reality of the observable physical universe (reductionism); that there is no objective basis for values other than what cultures and societies construct (relativism); and that human beings are ultimately and exclusively products of biological and socio-cultural forces (determinism). These taken-for-granted tenets of scientific materialism that allow no room for the workings of spiritual or non-materialistic forces in our lives are driven into our consciousness very early in our academic training.

But what if, as a result of field research in cultures outside the dominant orbit of western, "post-modern" understanding of reality, we become witnesses to phenomena that contradict the assumptions I mentioned above. Then what? How do we negotiate in our minds the severe cognitive dissonance that unavoidably results from the gross disparity between what we were led to believe is the true nature of the world, on one hand, and the way we experience that world on the other? This has been a recurrent dilemma among some anthropologists, who as participant observers studied shamanism in tribal societies (Harner 1982). Being fully aware of the possibility of trickery, they became witnesses to what they considered authentic phenomena that could not be accommodated within the limits and dominant paradigms of contemporary, western science.

This is what happened to me as I first encountered the healers of Cyprus, which led me to reconsider the dominant assumptions of academic, scientific culture about the nature of reality (Markides 1990, 1987, 1990). When we are confronted with such dilemmas, questions are bound to pop up in our minds: perhaps reality is much more than the physical universe; perhaps we are much more than what we permit ourselves to assume we are, namely biological organisms determined by our DNA and the cultural milieu within which we happen to be born; perhaps there is knowledge that goes beyond the rational mind, as many sages have argued from Pythagoras and Plato to the founder of sociology at Harvard Pitirim Sorokin (Sorokin 1947), to contemporary transpersonal theorists like Ken Wilber, to medical researchers like Larry Dossay and experimental psychologists like Dean Radin (Wilber 1998; Dossey 2014; Radin 1997) as well as leading scholars of comparative religions like Huston Smith (Smith 2002). These sages would argue that it is a mistake to assume that knowledge of the world is attained only through our rational faculty (philosophy and mathematics) and our senses (experimental science) but also, and most importantly, through intuition. Before his retirement from Harvard, Pitirim Sorokin argued for the honoring of all three strands of knowledge, for a more "integralist" and holistic understanding of Reality. In his dramatic writing style he claimed that: 
Side by side with the subconscious (or unconscious) and conscious levels in human personality, a third stratum - the supraconscious—is gaining increasing recognition. It is not the subconscious or unconscious, but the supraconscious energies that are beginning to be considered as the real source of all great human creations, discoveries and inventions in all fields of culture-science, philosophy, law, ethics, fine arts, technology, politics and economics ... . Such phenomena as extrasensory perception and psychokinesis, as the supraconscious religious experience of the great mystics; as precognition; as the so-called "calculating boys" or "arithmetical prodigies", as the state of samadhi of the yogi, or satori of the Zen Buddhists; as cognitive and creative intuition are neither subconscious nor unconscious, but supraconscious, and, as such are not reducible to the lower forms of vital and mental energy. ${ }^{4}$

To illustrate what I have suggested I will share some of my direct field experiences of healing phenomena with the Cypriot lay mystics; phenomena that I believe cannot be handled within the boundaries of established rationalistic and scientific paradigms. It is for this reason that, recognizing this problem right from the start, I preferred to employ a phenomenological approach in my field research. That is, I avoided imposing my own sociological categories in explaining the world of my subjects. Instead I asked them to explain their world from within their own categories of understanding.

One day, I received a phone call from a man in New York whose wife was suffering from a serious chronic illness that the doctors could not diagnose or identify. This man, who read my first book on the healers, asked me whether I could take along a picture of his wife to Daskalos (the leading healer I was studying) with the hope that he could perhaps identify the source of her problem. I volunteered to do so during my upcoming trip to Cyprus. When I gave Daskalos the picture he closed his eyes and with his hands began stroking and "feeling" the "vibrations" of the middle-aged woman in the picture. Then he opened his eyes and claimed that the problem of that woman was in her teeth. He said that her gums were all infected and that her teeth should be taken out and replaced with dentures. Because I thought his diagnosis was too outlandish, I was at first reluctant to write a letter to the person in New York. But at the insistence of Daskalos I overcame my initial hesitation, wrote the letter with his prescription and mailed it from Cyprus. Two months after I returned to Maine, I received another call from the same person (whom I had never met) to inform me that when he received my letter he threw it away considering Daskalos' radical suggestion sheer nonsense. Soon after, however, two of the front teeth of his wife fell out and infectious pus was dripping from her gums. She then went to an oral surgeon who took care of the infection and her physical problems disappeared. What were the probabilities, I wondered at the time, of someone making such an accurate diagnosis of the illness of a woman seven thousand miles away by simply touching her picture? In fact, some medical doctors today, based on their own experience, accept this unusual phenomenon as resting within the realms of possibility. A board-certified neurologist and psychiatrist like Dr. Mona Lisa Schulz, who calls herself a "medical intuitive", employs such an unconventional approach in her medical practice when traditional approaches to diagnosing illnesses do not work (Schulz 2005).

Daskalos, a high school graduate, not only healed an Israeli woman suffering from psychiatric problems that reputable psychiatrists could not cure, but also healed a local woman from spine problems after leading doctors in Cyprus and in Israel concluded that there was no cure for her problem. These experts suggested to her that she should get used to the idea that she would spend a large part of her life lying in bed. After Daskalos's intervention (a matter of forty-five minutes of barely touching her back, a procedure that I witnessed with my own eyes) the patient got out of bed and was able to live a normal life from that very day. After the healing, the X-rays that she took that

4 In Willis Harman and Howard Rheingold, Higher Creativity: Liberating the Unconscious for Breakthrough Insights (Jeremy P. Tarcher 1984)—quoted in (Markides 1990, pp. 181-82). 
same afternoon showed a healthy, normal spine, in contrast to the X-rays she had taken a week earlier. On another occasion, the Cypriot healer accurately alerted a friend of mine, the late Leonard Doob, Yale psychology professor, of a liver infection by simply casually chatting with him. The healer warned him that he should never donate blood to another person since, even though he reassured him that his illness was not life threatening, he would always be a carrier of the virus. My friend dismissed Daskalos' uninvited diagnosis and advice. He had just had a physical examination in New Haven, and had been declared perfectly healthy by his physicians. But three months later, after we returned to the States, he contacted me from Yale. He said the doctors discovered Hepatitis B on his liver, exactly as mentioned by "your healer", as he referred to Daskalos. His doctors claimed that it was impossible for anyone to detect the virus on his liver, as it takes three months to incubate and thus become noticeable through medical instruments. That means that when Daskalos told him that he had a virus infection the virus was already on his liver at the early stages of incubation, but could not have been detected by any traditional physician using state-of-the-art medical technology. Yet the healer in Cyprus "saw" the infection, not with any instrument, but with his consciousness. As Daskalos explained to Leonard the following summer, he used a different faculty of cognition unknown to medical science. In another instance, using such a special faculty, he accurately described in minute detail the inside of our house in Maine when he had never been to the U.S. He even suggested humorously that we needed to install a telephone on the second floor of our house to avoid the risk of falling down the steps every time the telephone would ring in the kitchen! One time, he contacted us to urge Emily to see a doctor about a problem on her knee, when we had told nobody in Cyprus that she had a knee problem.

Of course these are anecdotal experiences and stories that cannot be supported scientifically. Speaking for myself, however, I cannot deny my own experience. Additionally, an increasing number of reputable observers have been reporting similar experiences in other social and cultural settings. Even as long ago as the early sixties Dr. Jerome Frank, hard-nosed scientist and professor of psychiatry at Johns Hopkins University, could state in his classic work Persuasion and Healing:

Some individuals may have a gift of healing that defies scientific explanation. ... Nor can one rule out the possibility-indeed the evidence for it is quite persuasive-that some healers serve as a kind of conduit for a healing force in the universe, often called the life force, that, for want of a better term, must be called supernatural (Frank 1974).

Another scientist with impeccable credentials that drew similar conclusions is the neurologist and acclaimed brain researcher Dr. Wilder Penfield, who pointed out in The Mystery of the Mind (Penfield 1975) that for most of his life he had been a total materialist, believing that mind cannot exist independently of the brain. Yet on the basis of his research, he recognized that certain functions of mind could not possibly be explained on the basis of the material brain. That led him to the conclusion that the mind cannot be contained within the brain and that the latter is simply a vehicle for the former. One reviewer stated that:

“The Mystery of the Mind is Widler Penfield's apology for his belated conversion from monism to dualism. That may not sound like much, but Professor Penfield, now at the end of his career as a pioneering neurosurgeon and explorer of the brain, has come to the conclusion that brain and mind are separate entities and that, while the mind is ordinarily dependent on the brain for its activity, it cannot be explained entirely by brain mechanisms. In a field where many workers will not even admit the existence of nonphysical realities like mind, that is quite a conclusion ... I once heard a Hindu yogi tell a group of Western scientists that 'all of the brain is contained within the mind, but not all of the mind is in the brain.' To hear a Western neurosurgeon say something similar is most remarkable." (No Author 1976).

Unusual phenomena have also been studied and recorded diligently by parapsychologists, carrying out their work under controlled experimental conditions. A vast body of such studies has 
been accumulated during the last one hundred years, ever since the establishment of the Society for the Study of Psychical phenomena by British scientists at the close of the 19th Century. ${ }^{5}$ Yet, with very few exceptions, mainstream scientists would refuse even to consider the evidence, presuming that such phenomena are not phenomena at all. Reacting to this prejudicial attitude on the part of mainstream scientists, British author and philosopher Colin Wilson wrote:

Skeptical scientists living in London or New York have already concluded that the paranormal does not exist because it cannot exist. Almost without exception they would not take the trouble to go and see a psychic surgeon even if one lived round the corner: they tell you wearily that they know nothing will happen, or that if it does it will be trickery. All they are prepared to do is to consider the evidence at second hand, preferably in some easily digestible form, for they all lack patience, and then think up objections. And the result of their deliberations is then accepted by the rest of the scientific community as the unbiased conclusions of hard-headed scientists. In fact it is little more than a regurgitation of the opinions they have been expressing for years, opinions which are change-proof because the scientists have no intention whatever of studying the evidence (Wilson 1988).

To consider "paranormal" phenomena (in the Athonite language, "miracles") seriously would imply a willingness to radically revise our materialistic and reductionist assumptions about reality, and seriously entertain the notion that the mind is not confined within the brain; that it may be, in fact, "non-local", and that soul and spirit may be realities that must be factored in for a fuller understanding of self, society and cosmos (Fontana 2003). Furthermore, we must be open to the possibility that a sizable number of people who live ordinary, normal lives also have experiences that can be called "paranormal" or "non-ordinary", or "miraculous", but because of the dismissal of such experiences by mainstream scientists as nothing more than delusions or hallucinations, such individuals prefer to remain silent, lest they be stigmatized as mentally ill. I have been a witness to this problem time and again. When my books came out on the healers and mystics of Cyprus, scores of individuals contacted me to reveal that they themselves live within the realities that I described in my books, but prefer to remain quiet about them lest they be ridiculed, stigmatized and/or fired from their jobs. And these are individuals from all walks of life, including scientists and academics!

As I mentioned earlier, the extraordinary healing phenomena and "paranormal" abilities that I had witnessed in my work with Daskalos and his circle of mystics and healers prepared me for my personal "discovery" of Mount Athos. A friend familiar with my work urged me to join him on a journey to Mount Athos to meet "real saints." (Markides 1995) Their prayers, he claimed, are so powerful that healing miracles and other extraordinary phenomena are routine matters. I took up his invitation and my exploration and life took another turn.

In my years studying Athonite elders, I have heard of similar miraculous recoveries from physical and psychological illnesses after an elder prayed for the healing of the suffering individual. In recent years there emerged a plethora of books (mainly in Greek) on the miraculous lives of contemporary saints like elders Porphyrios and Paisios that, even though not "scientific" in the traditional sense, could dispel doubts related to the authenticity of the extraordinary lives of these elders. Having personally and directly witnessed healing phenomena during my work with the Cypriot lay mystics I was now open to such possibilities in the lives of venerated elders and Athonite monks and hermits.

Here is one of many concerning Elder Paisios, whom I met two years before his death in the early 90 's. He was seeing pilgrims all day long in his hermitage on Mount Athos. By four o'clock in the afternoon, he announced that he was tired and could not see any more pilgrims. One of his visitors was very distressed, as he was eager to have a private meeting with the Elder. "Please Father," he implored, "I must see you. It is for my wife." "Sorry my son, but I am very, very tired." "But Father,

5 See for example the extensive survey of such research (Brown 2005). 
my wife is dying. I need to talk to you." This pilgrim wanted to ask Elder Paisios to intercede with God and pray for the healing of his wife who was dying from cancer. The Elder tapped his visitor on the back and said, "Go my son, and your wife is okay".

That pilgrim went back to Athens feeling that his journey several hundred miles away had all been in vain. When he entered his house his wife, who had been bedridden, was up and moving about the house. Later the doctors verified that, miraculously, her tumor had disappeared. She explained that as she was lying in bed, she felt heat all over her body, as if her cancer was melting away. It was during the hour when Elder Paisios told her husband "Go my son, and your wife is okay".

The Athonite culture is replete with tales not only of healing phenomena like the one I just described, but also of other types of extraordinary mystical experiences, of stories about the materialization and dematerialization of sacred icons, of teleportation, out-of-body travel, levitation and the bi-location of holy elders. These are stories that one usually reads about in the mystic traditions of Hinduism and Tibetan Buddhism (Yogananda 1987; Sogyal 2012). I was fascinated when I realized that such tales are much alive in the very heart of Christianity. I further noticed that Mount Athos preserved a system of "eldership", of a master/disciple relationship that again I had assumed up to that point was the exclusive hallmark of the religions of the far east. I am saying this because what attracted contemporary westerners, myself included, to the religions of India and Tibet is the emphasis on an experiential, mystical approach to the Divine, something that we felt was lacking in western Christianity. But since my encounters with Daskalos and his group, and my experiences with Athonite elders, I have realized that mystical spirituality is very much alive within the bounds of western civilization, in the cultural remnants of the eastern part of the Roman Empire. We have simply ignored that reality because of the triumph of scientific rationalism and certain other historical and sociological reasons that are beyond the scope of this paper.

The person who served as my key informant and mentor in the healing, mystical culture of Eastern Orthodoxy was Father Maximos, the thirty-three-year-old monk whom I met on my first visit to Mount Athos in 1991. He had already lived more than a decade as an Athonite ascetic intending to spend the rest of his life on the Holy Mountain. But following the requests of his elders he left Mount Athos in 1993 and became the abbot of the Panagia monastery in the Troodos mountains in Cyprus. There, he served as the spiritual guide to about thirty-five monks and forty nuns from a near-by women's monastery. Quickly developing a reputation as a spiritually gifted elder, he was sought by hundreds of lay people for confession and counseling; so much so that he was considered the person mostly responsible for a monastic renaissance on the island. It was in Cyprus that I joined him as a resident scholar studying his life and work, while also serving as his temporary chauffer, a task that allowed me more time to converse with him. During many hours of direct observation on my part, and conversations related to the subject matter of my work, I came to appreciate the spiritual tradition within which I had grown up. I had been alienated from that tradition since my arrival in America, which began the inevitable process of my secularization and absorption into the skeptical culture of academic social science. Father Maximos exposed me in a direct, personal way to the healing culture of Orthodoxy and its "apophatic" theology. It is from him that I first heard the novel idea that the Ecclesia must be seen first and foremost as a spiritual hospital, a healing institution; and that theology as a discipline should be part of medicine and not the humanities, as it has traditionally been considered. Like medicine, the central focus of the Ecclesia must be healing; most importantly the healing of the self, which is alienated from its true divine homeland. This is accomplished, as I will show later, through the application of specific healing methodologies that have practical and observable results (Markides 2001, 2005, 2012).

Perhaps a good way to introduce this Orthodox healing tradition is to briefly narrate two interrelated stories. The first story is that of a death row inmate that I will call David, who several years back wrote to me after reading the books I wrote related to the Cypriot lay healers. He asked for my assistance in connecting him with someone who could offer him spiritual advice. In his letter, he stressed the urgency of his request, as he did not know how much time he had left before his 
execution. He did not reveal what his offence was, other than that he had been involved with drug trafficking. I assumed he was convicted for murder. He also pointed out that he was a college graduate and in fact held a masters degree in English literature. It was clear from the quality of his letter that he was an educated person.

Without hesitation, I sent him the address of Father Maximos. Several months later David wrote to me again. He thanked me for the contact and claimed that in his entire life he had never experienced so much love coming to him as he felt coming through the letters of Father Maximos. They maintained regular correspondence as Father Maximos offered spiritual advice while providing him with classical texts on Orthodox spirituality (such as The Way of the Pilgrim and The Philokalia). This contact was decisive in David's personal transformation and atonement, as will become clear from the second story, which is, in a most unusual way, linked to David's fate.

About the same time that I received David's letter, a Texan businessman called me to relate an experience he had undergone while a pilgrim on Mount Athos. He introduced himself as a very wealthy man who had made his fortune in real estate. At one point in his life he had had a car accident that had left him mentally incapacitated. He had lost most of his memory and was unable to do simple arithmetic; a man with a masters degree in mathematics, and a second masters in business administration. At the urging of a friend-an Orthodox priest-this Texan (as I will refer to him), who was not Orthodox, decided to join him on a pilgrimage to Mount Athos. While walking from one monastery to another, they spotted a hermit dressed in rags plowing his garden. The Texan felt pity on him and offered him some money. When the hermit refused his generous offer, his friend explained that the reason why he is a hermit is precisely to live beyond worldly temptations. "But if you wish to give him some money to buy candles and light them in church for your healing he will do so", the Orthodox priest suggested. When that was clarified, the hermit accepted a small sum. He then placed his hands on the head of the Texan and began murmuring some Greek prayers that the Texan could not understand. "I thought for a moment", he told me over the phone, "that the old hermit living by himself in the wilderness was half demented." When the Athonite hermit finished his prayer, he turned to the Greek American priest and said "Your friend is whole now." Then they continued their hike. Just as they reached their destination, outside the gate of the next monastery, the Texan's memory was suddenly restored. He was "whole" again. Overwhelmed by his experience, he decided to devote time and money to help set up an Athonite monastery in the United States. And this is what happened. A septuagenarian elder from Mount Athos, reputed for his charismatic and prophetic gifts migrated to the United States and, with the help of the Texan and other patrons, set up a monastery in the middle of a desert in the American South West. The story of how it was located in the desert is a "miracle" in itself. I was told that while they were roaming the desert in a jeep searching for an appropriate location to buy land, they heard bells ringing. For the elder, that was a sign from heaven that they had found the right place, and he asked his companions to buy the land. They pointed out, however, that there was no water anywhere nearby and that the state would not allow the building of anything without a reliable water supply. The elder insisted. Obedient to their spiritual guide and elder, the Texan and the others bought a large portion of desert land knowing that they were "throwing their money away." As they predicted, the state refused a permit without first securing a water source. Then according to the story the elder, like an Old Testament prophet, went into the desert for three days of fasting and ceaseless prayer. On the third day he came out of his fasting and prayer and announced the spot where they should dig to find water. Lo and behold, after drilling deep into the desert floor they discovered a huge underground lake. The monastery was built and in a matter of six years the desolate land was transformed into a veritable oasis with thousands of pilgrims visiting each year hosted by over forty monks. In the meantime, plans were made to create a women's monastery nearby.

Interestingly, the monastery was an hour away from the maximum-security prison where David was being held. Furthermore, the abbot of the monastery (not the spiritual elder who created the monastery) was a friend of Father Maximos from their years together on Mount Athos. Father Maximos requested that his friend take up the case of David, and after nine months of persistent effort, 
the authorities eventually gave permission to the bearded black-robed monks from the monastery to meet with David. They designed for him a program of spiritual practices and prayer meditations for his spiritual recovery. It was a program based on the ascetical traditions of Orthodox monks and hermits.

In his last letter to me, David said that the best thing that happened to him was to be arrested and sentenced to death. On death row, he said, he had discovered God. Had he remained out in the world, living the kind of life he had lived would have led him to a spiritual death. Now he is spiritually alive. No longer fearing death, his prison cell is his Athonite hermitage that helped him find himself and heal his soul. There is no question, according to Father Maximos and the monks who guided him on his spiritual journey, that David's metanoia (radical change of heart and mind, repentance) is genuine. He may eventually be executed, but he has been healed at the very core of his being. And this is what ultimately matters as far as Orthodoxy is concerned.

I believe these two parallel stories, the radical transformation of David and the mental recovery of the Texan businessman, are archetypal of the salient features of Eastern Orthodoxy: a healing tradition, a miracle tradition and a desert tradition. It is a healing tradition insofar as its ultimate goal is to heal the soul at its very core. David, through deep metanoia, was in the process of being spiritually healed from the vast chasm between him and God that had resulted from the kind of life he had carried on while living in the world. According to Orthodoxy, the ultimate goal of all human beings is in fact to re-establish this unity between us and God that was originally shattered as a result of the mythic Fall of Adam and Eve.

Furthermore, Orthodoxy is a miracle tradition in that the life of those who are reputed for establishing that direct connection with God-that is, the saints and holy elders-become vehicles for the healing energy of the Holy Spirit, which can cause miracles to happen not only on the spiritual and psychological levels, but also on the physical level, as in the case of the Athonite hermit who is credited for healing the Texan pilgrim, and Elder Paisios healing the woman who suffered from cancer. In fact, miracles are the sin qua non of what is, as a rule, required before one can be declared a saint by the Ecclesia. And these miracles must take place while the saint is alive and after he or she departs from this world. Mount Athos and Orthodoxy in general are filled with miracle stories of healing phenomena.

Lastly, in Eastern Orthodox mystical spirituality, the desert plays a prominent role, both literally and figuratively, in the development of its theology and spiritual practices. Once Christianity was established as the official religion of the Roman Empire in the early part of the fourth century, the new "martyrs", as living witnesses to the faith, were hermits, like the Great Anthony, who abandoned the comforts of city life and entered the desert to find God through ceaseless prayer, contemplation and spiritual exercises. This tradition is preserved to the present day in ancient monasteries like those of Mount Athos that cultivate inner silence so that the practitioner may hear the voice of God. That is, the way to reach God and unite with God is to create space within us, an "inner desert" so to speak, free of egotistical passions, and within that silence, God's voice will echo into the depths of our hearts. The full-time practitioners of this inner silence are the ascetics from whose ranks came most of the leading saints and the great theologians of Eastern Christianity. These holy elders provided the foundations of its healing tradition as well as its mystical theology.

As I learned from Father Maximos and other elders, the hallmark of Eastern Orthodox mystical spirituality is what I have called The Three-Fold Way (Markides 2001, pp. 212-24). The holy elders teach that the re-establishment of the shattered unity between human beings and God proceeds in three identifiable stages: Catharsis (the purification of the soul), Fotisis (the enlightenment of the soul) and Theosis (union with God). Below, I will summarize these three stages. I am struck by their universality. They can be considered the necessary and fundamental path that all human beings must traverse before they re-unite with God, the ultimate healing of the Self and the soul's final destination.

The premise upon which The Three-Fold Way stands is the belief that human beings, since time immemorial, have fallen from Grace. They have shattered their connection with God and live their 
lives in a state of exile from their true homeland. This is the meaning of "original sin" as understood by the mystical holy elders of Eastern Christianity. A key pre-condition for union with God, as I mentioned, is that the individual undergoes deep metanoia which will lead to the process of catharsis and purification of the soul from egotistical passions. The story of Genesis in the Old Testament and the Parable of the Prodigal Son in the New Testament allude to this fundamental existential truth about human origins and destiny. In the Parable, the prodigal son left the palace of the loving Father and cut himself off from his heavenly, spiritual roots. He eventually squandered his divine inheritance by indulging in the various passions and temptations of the material world. The Prodigal's entire human nature was distorted and the passions that were given as properties of the soul to celebrate the Creator were now employed for the satisfaction of egotism. For example, the capacity of the soul for anger, given to the soul as the power to resist temptation and sin, became a source of discord among human beings both individually and collectively for the satisfaction of lowly desires. Similarly pride in one's divine lineage becomes pride over one's possessions, craving for attention and fame, power over others and so on. I must admit that I found this interpretation of the parable compelling.

At a certain point the Prodigal son is exhausted from his miserable existence (which is life cut off from God) and begins to yearn for the Palace. This is the beginning of the return journey. The Prodigal, after great difficulties and tribulations, eventually returns, and the Father embraces him and orders a feast to celebrate the return of His lost son. I realized that this was meant to be an allusion to the story of every human being who yearns for a connection with God and begins the process of metanoia and catharsis. The Palace, this Inner Kingdom, is always part of us but we do not recognize it because it is covered up by poor habits, inattention, and materialistic desires. The Prodigal Son never stops being a prince even while living among the pigs (notice the similarity of the Prodigal Son story with Plato's parable of the Cave).

The Christian elders teach that the process of healing and the restoration of the soul requires arduous spiritual struggle and effort. This is a point also made by modern religious thinkers. It is a point often lost on a culture that values instant gratification. The Ecclesia, based on its accumulated experiences resulting from the lives and teachings of its saints and holy elders, provides a methodology for how to heal the soul, how to free ourselves from egotistical desires and reestablish our connection to God. This methodology is called askisis which literally means exercise. The full-time practitioners of askisis are ascetics, whose practices and discoveries can help those of us who live in the world to proceed on our journey of re-union with God. It is this askisis that the American Athonite monks taught David in order to help him heal himself from the vast abyss that he created separating him from God's Grace as a result of his earlier life.

Among the set of practices that form askisis are regular participation in the sacraments of the Ecclesia like confession and communion, charitable action in the world, fasting, ceaseless prayer, systematic study of sacred texts and the life of saints, cultivation of deep humility, communal worship and so on. Charity, when given freely and unselfconsciously, is important in all its facets (material and non-material giving and caring for the other) as a way of forgetting our own self-absorption and our tendency to imprison our hearts within the things of this world. Similarly, fasting trains the soul to master the lower passions. The logic behind it is that, unless you learn gradually to overcome small temptations, such as avoidance of certain foods, you will not develop the power to resist greater temptations that unavoidably assault our everyday existence. Confession too, through the spiritual guidance of an experienced elder is essential so that we not only address our sinful actions but we can most importantly become conscious and thus monitor our logismoi, the negative thought-forms that we constantly generate in our minds, which deposit layer upon layer of separation between us and God. We are called to replace these logismoi with systematic and ceaseless remembrance and contemplation of God through prayer. A most important practice is the incessant repetition of short prayers, foremost of which is the Noera Prosefche, or the Jesus Prayer ("Lord Jesus Christ, Son of God Have Mercy on Me"). The practitioner is asked to repeat this prayer as much as possible. It can be recited even while engaging in worldly activities like waiting at a bus stop or washing dishes. 
The purpose of this practice is to minimize the creation of negative thought-forms and replace them with the memory of God as a vehicle for re-capturing the paradisiacal stage-which can be attained, by the way, in one's present life. For the holy elders, of course, the Jesus Prayer is an invocation of the Holy Name that in conjunction with reciting long-established prayers like the Psalms, reading about the lives of saints, and attending regular communal services, eventually will bear fruit in the life of the practitioner. There are variants to the Jesus Prayer, like that of Saint Gregory Palamas who used to pray "Lord Enlighten my Darkness", over and over.

At a certain point, for the soul that engages in askisis and the systematic catharsis from worldly passions, Fotisis will follow. At this stage, when the soul has undergone its purification and after attaining depths of humility, Divine Providence offers the soul extraordinary gifts such as contemplating the "Uncreated Light" (God's light), prophetic vision, healing abilities such as those mentioned earlier, phenomena of levitation and bi-location and the like. These gifts are deeply buried within human nature, and as a rule become manifest after the purification of the soul. Therefore, what we call "paranormal" phenomena are in reality very normal at this second stage. These are the gifts that are reported in the lives of saints who serve as models for us of what we may be.

The most prized gift of the Spirit, as far as the saints are concerned superseding all other gifts, is the vision of the Uncreated Light, the mystical contemplation of God's presence in the world that floods the soul with exquisite joy. The following is an example of such an experience as narrated by Elder Joseph from the Vatopaedi monastery of Mount Athos:

"I remember clearly that as soon as I began to mention in my prayer several times the name of Christ my heart filled with love. Suddenly it increased so much that I was no longer praying but I was in a state of wonder about this overflowing of love. I wanted to embrace and kiss all human beings and the entire creation and at the same time I was thinking so humbly ... . I felt the presence of our Christ but I could not see him. I wanted to fall down to His immaculate feet and ask Him how does He set fire to the hearts of people and yet remain hidden from them. I was then given to understand that Christ is inside every human being. I said, my Lord let me be in this state forever and I need nothing else. This state lasted for some time and when I came back to my original condition I couldn't wait until I went to my gerontas (elder) to tell him all about it ...."

He further had this to say on the matter:

"When the mind of the person has been cleansed, purified and enlightened ... . it is given, in addition to its own light, the light of Divine Grace so that it remains permanently within him. Then it snatches him and exposes him to visions and perceptions true to its own nature. However, such a person has the capacity, if he so wishes, to ask through prayer. Then Grace is energized and what he asks is given simply because he asks. But I believe the truly devout avoid such requests except in extraordinary circumstances." (Joseph 1984; Markides 1995, pp. 302-3)

As Elder Joseph states, those who are offered such gifts of the Spirit accept them in utter humility, and they must never be a source for self-promotion and self-aggrandizement. In fact, such gifts may also be strong temptations that can often lead to a spiritual fall. That is why great saints do their utmost to hide them and use them only sparingly and only to help fellow human beings in their spiritual, psychological and medical needs. It is for this reason also that the desert fathers have been called nyptic, meaning vigilant. They were constantly fully conscious and on guard against such temptations. Therefore, from the point of view of the holy elders of Orthodoxy any healing ability that one may be endowed with should not be flaunted for the sake of impressing an audience as happens so often today among certain "New Age" circles. I remember the strong reaction of Elder Paisios when I naively asked him about his reputed abilities to heal people. He emphatically denied such "rumors", stating that all he does is pray for people, and that whatever healing takes place is the 
result of God's Grace and Providence. Yet these rumors crossed the Atlantic, reaching me in Maine when I first heard of him and of his reputed friendship with wild animals like bears and poisonous snakes. In Orthodox spirituality, the God-realized individual who has reached paradise in this life re-establishes a harmonious relationship with nature that was a characteristic of life before the Fall. Hence the legends of saints who lived among wild beasts without fear of being harmed.

Finally, the third stage in the spiritual development of the self is the attainment of Theosis, the ultimate destination of the human soul and its restoration into the oneness of God. It is the ultimate healing of the soul. Like the previous stage of Fotisis it is totally in the hands of Providence. Human beings cannot re-unite with God strictly on their own accord. Our will must be engaged only at the first stage, the stage of Catharsis. The other two stages follow naturally as God's rewards, as it were, for our struggles to purify our hearts. Therefore, attempts to get to those "Gifts" directly (for example trying to develop one's psychic powers per se) without at the same time struggling to free the soul from egotism, may be the equivalent of "stealing from God", leading to what has been called "black magic".

All of the great sages have pointed out that the oneness with God, at Theosis is beyond all human description or comprehension. I should also point out that in Christian spirituality, the soul upon its return home maintains autonomy within the oneness of God. The self does not get diluted into the All. What is annihilated is the sum total of our egotistical passions and desires, not our uniqueness as persons created in the image of God for eternity. This is a big difference, with some notions stipulating that the final end of spiritual development is the obliteration of personhood, a form of spiritual nihilism. The God-realized human being will retain his or her uniqueness within God while continuing from the paradisiacal side to work for the salvation of others. It is also important to repeat that Theosis is not a stage that one can reach only after one is dead but while one is still alive and active in this world. The paradisiacal stage, the ultimate healing of the human person, is possible from this side of the divide. Our paradise or our hell can start from this life.

Before ending this section, a caveat is perhaps needed here. It would be a mistake to assume that the Athonite elders, abbots, and monastics that I have encountered over the years and written about are perfect souls. They are not infallible. Like all human beings, they make mistakes, and often grave and, yes, appalling mistakes. They do so as a result of the limitations of their formal education and the social and cultural constraints they find themselves in. In this respect it is important to remember that this has been the case with the greatest of saints of the Christian tradition, past and present. Are we, for example, to reject the wisdom of St. Paul because of what has been attributed to him as forms of misogyny and homophobia? Or are we to discredit the entire corpus of St. John Chrysostom because of his alleged antisemitism? Many "cultured despisers" of religion (to borrow Friedrich Schleiermacher's graphic phrase) focused on whatever shortcomings they could uncover and debunk, and discredit wholesale the entire enterprise of monastic life and teachings. It is important, therefore, not to over-idealize monastic communities and expect the behavior of its members to be of the quality, literally speaking, of the angelic orders! Otherwise we may be massively disappointed and in the process deprive ourselves of the benefit of whatever accumulated wisdom is preserved in these institutions over the centuries.

\section{Summary and Conclusions}

I have tried to show in this paper that in the monasteries of Eastern Orthodoxy, perhaps more so than in any other part of the Christian world, a healing mystical tradition has been preserved (the Three-fold Way) that we assumed was only prevalent in religions like Hinduism, Tibetan Buddhism and native shamanism. Many westerners, disenchanted with the prevailing rationalism of mainstream culture, both in terms of its religious and scientific expression, have turned towards the far east for an experiential and miraculous pathway to Reality, while all the time one has existed right within Christianity. 
I have also tried to show that the increasing interest among modern individuals in "paranormal" and miraculous phenomena (angels, prophetic visions, out-of-body travel, near-death experiences, extraordinary healings, etc.), dismissed by doctrinaire skeptics as non-phenomena, have been the sin qua non of the life of Eastern Orthodox saints and a hallmark of Eastern Christianity. Therefore, the miracle, mystical culture of Eastern Christianity might be of interest not only to mainstream Christians of all denominations, but also to an increasing number of westerners who have been attracted to the mystical religions of the East and their New Age variants, a trend that has become so much a part of our cultural and religious landscape today.

Potentially, the Three-fold Way of Eastern Orthodoxy can contribute to the development of what transpersonal theorists call "the eye of contemplation", namely the cultivation of the intuitive, spiritual side of human beings that has been repressed over the last few centuries because of the triumph of rationalism and scientific materialism. This has led to what sociologist Max Weber called the "disenchantment of the world" and theologian Philip Sherrard lamented as "the desecration of the world."(Sherrard 1998) The spiritual methodologies that have been preserved in ancient monasteries of the Christian East may play a role in overcoming positivism, reductionism, relativism and determinism, ideologies that have dominated our higher culture during the last three hundred years. It will be remembered that it is the mystical side of Orthodoxy that led literary masters like Tolstoy and Dostoevsky to be frequent patrons at the famous monastery of Optina, destroyed by the Bolsheviks during the aftermath of the Russian Revolution. It is there that they nurtured their spiritual view of reality, and it is there that Dostoevsky met the elder that he fictionalized in his Brothers Karamazov as "Father Zosima".

The question comes to mind, of course, whether Eastern Orthodoxy as it presents itself today to the rest of the world is ready to play a historical part in the "re-enchantment" or the "re-sacralization" of the world. I posed that question to Kallistos Ware (retired Lecturer of Eastern Orthodox Studies at the University of Oxford and an Orthodox bishop himself) in a recent interview (Markides 2005, pp. 148-77). His answer was unambiguously in the negative, as I would have expected from anyone who understands the state of affairs of the Eastern Church. What are the problems, then, that seem to be obstacles that prevent Orthodoxy from making a contribution to an emerging, modern culture? Here is a short summary.

The eastern part of Christianity, because of historical reasons (triumph of Islam and communist takeover), remained cut off from the cultural and historical forces that shaped the modern age. This isolation from western cultural and intellectual developments (such as the Enlightenment) has served as a double-edged sword. On one hand it helped preserve the Three-fold Way. On the other hand, Eastern Christianity has shown serious deficits and gaps in its ability to deal creatively with the intellectual challenges of a world that is rapidly becoming global and culturally diverse. Therefore, the temptation is strong to nurture an insular fundamentalism, a tendency not only to be indifferent to an understanding of other religions, but to monopolize God, as it were, by demonizing other religions as nothing but heresies. Another difficulty is the tendency of some theologians to nurture hostility towards the West as if they are still living during the time of the Fourth Crusade, when Constantinople was ransacked by the holy warriors of the West, paving the way for the Ottoman takeover of Byzantium. Such xenophobic attitudes are painfully pronounced among several segments of the ecclesiastical establishment of the Christian East. I have time and again been amazed by the extremely reactionary political, religious and cultural utterances of some members of the higher clergy, including Athonite monks. With an inability to understand the modern world and its pluralistic texture and a concomitant wholesale rejection of its cultural values (equality of women, diversity as good rather than demonic), they make it difficult for westerners to discover for themselves the hidden spiritual and healing treasures found in the monastic tradition that I have presented in this paper. Westerners with a thirst for spiritual healing and experience will simply look elsewhere: in the ashrams of India, in Zen meditation monasteries, in native American sweat lodges. These traditions are outside of the cultural baggage that has plagued the troubled histories of the Abrahamic religions. But I remain positive 
and hopeful. There are many enlightened ones: theologians, monks, patriarchs, and bishops who, being inspired by the mystical teachings of the holy elders, are struggling against such narrowness of vision and quietly working for an open dialogue, understanding and cooperation among the religions. May their efforts bear fruit for the good of Orthodoxy and the World. For I do believe that the mystical pathways of Eastern Christianity can contribute immensely not only to the healing of individual souls, but to the healing of our troubled world, stranded as it is in the quick sands of materialism. We have come to this point by falsely assuming that ultimate reality is the reality of our sensate, observable universe, an ultimately nihilistic outlook on life. The saints and holy elders of Eastern Christianity might help us find our way out from our present predicament.

Conflicts of Interest: The author declares no conflict of interest.

\section{References}

No Author. 1976. New York Times Book Review. New York Time, January 18.

Brown, Courntney. 2005. Remote Viewing: The Science and Theory of Nonphysical Perception. Atlanta: Farsight Press.

Dossey, Larry. 2014. One Mine: How Our Individual Mind Is Part of a Greater Consciousness and Why It Matters. New York: Hay House.

Fontana, David. 2003. Psychology, Religion, and Spirituality. Oxford: Blackwell.

Frank, Jerome. 1974. Persuasion and Healing. New York: Schocken Books.

Harner, Michael. 1982. The Way of the Shaman: A Guide to Power and Haling. New York: Bantam.

Joseph, Monk. 1984. Geron Ioseph Oh Hesychastses. Daphne: Agion Oros. (In Greek)

Lossky, Vladimir. 1997. The Mystical Theology of the Eastern Church. Yonkers: St. Vladimirs Seminary Press.

Markides, Kyriacos C. 1990. The Magus of Strovolos: The Extraordinary World of a Spiritual Healer. New York: Penguin; Abingdon-on-Thames: Routledge and Kegan Paul. First Published in 1985.

Markides, Kyriacos C. 1987. Homage to the Sun: The Wisdom of the Magus of Strovolos. New York: Penguin/Arkana. Markides, Kyriacos C. 1990. Fire in the Heart: Healers, Sages, and Mystics. New York: Penguin/Arkana.

Markides, Kyriacos C. 1995. Riding with the Lion: In Search of Mystical Christianity. New York: Viking.

Markides, Kyriacos C. 2001. The Mountain of Silence: A Search for Orthodox Spirituality. New York: Doubleday.

Markides, Kyriacos C. 2005. Gifts of the Desert: The Forgotten Path of Christian Spirituality. New York: Doubleday.

Markides, Kyriacos C. 2012. Inner River: A Pilgrimage to the Heart of Christian Spirituality. New York: Doubleday.

Meyendorff, John. 1974. St. Gregory Palamas and Orthodox Spirituality. Yonkers: St. Vladimirs Seminary Press.

Penfield, Wilder. 1975. The Mystery of the Mind. Princeton: Princeton University Press.

Plested, Marcus. 2012. Orthodox Readings of Aquinas. Oxford: OUP.

Radin, Dean. 1997. The Conscious Universe: The Scientific Truth of Psychic Phenomena. New York: Harper Collins. Sogyal, Rinpoche. 2012. The Tibetan Book of Living and Dying. New York: Harper Collins.

Schulz, Mona Lisa. 2005. The New Feminine Brain: How Women Can Develop their Inner Strengths, Genius and Intuition.

New York: Free Press.

Sherrard, Philip. 1998. Christianity: Lineaments of a Sacred Tradition. Brookline: Holy Cross Orthodox Press.

Smith, Huston. 2002. Why Religion Matters. San Francisco: Harper.

Sorokin, Pitirim A. 1947. Society, Culture and Personality. New York: Harper.

Stark, Rodney. 2006. The Victory of Reason: How Christianity Led to Freedom, Capitalism, and Western Success. New York: Random House.

Stark, Rodney. 2014. How the West Won: The Neglected Story of the Triumph of Modernity. Wilmington: Intercollegiate Studies Institute Press.

Ware, Kallistos. 1995. The Orthodox Way. Yonkers: St. Vladimirs Seminary Press.

Wilber, Ken. 1998. The Marriage of Sense and Soul: Integrating Science and Religion. New York: Random House.

Wilson, Colin. 1988. Beyond the Occult. New York: Carroll \& Graf.

Yogananda, Paramahansa. 1987. Autobiography of a Yogi. Los Angeles: Self-Realization Fellowship.

(C) 2017 by the author. Licensee MDPI, Basel, Switzerland. This article is an open access article distributed under the terms and conditions of the Creative Commons Attribution (CC BY) license (http://creativecommons.org/licenses/by/4.0/). 